\title{
Kristlike usuliikumiste mõju eestlaste ja eestirootslaste rahvakunstile ja kultuurile ${ }^{1}$
}

Teesid: 18. ja 19. sajandil levisid Eestis uued usuliikumised, mis osaliselt tegutsesid luterliku kiriku sees, aga enamasti väljaspool seda, levides kohati ka õigeusu kiriku liikmete seas. Neist mõjukaimad kogu Eesti ulatuses olid vennastekoguduse ja taevaskäijate liikumine ning peamiselt Lääne-Eestis 19. sajandi lõpuveerandil levinud usuliikumised, mille tulemusena moodustati esimesed Eesti vabakogudused.

Nende usuliikumiste võitlus eestlaste ja eestirootslaste rahvakultuuri, sh rahvakunsti ja rahvausundi patusteks peetud ilmingute vastu on kohati olnud hämmastavalt edukas, eriti Saare-, Lääne- ja Hiiumaal. Artiklis vaadeldakse selle võitluse käiku ja mõju 18. ja 19. sajandi külaühiskonna kontekstis.

Märksõnad: usuliikumised, rahvakultuur, rahvakunst, vennastekogudused, eestirootslased

Käesolevas artiklis käsitletakse 18. ja 19. sajandil alguse saanud suuremate Eesti kristlike usuliikumiste mõju Eesti rahvakultuurile ja eriti rahvakunstile, eeskätt rahvapärasele käsitööle, muusikale ja laulule, tantsule ja jutuloomele. Need usuliikumised on vennastekoguduse ja sellega seotud taevaskäijate liikumine ning 19. sajandi lõpuveerandi usulised ärkamisliikumised, mis levisid peamiselt Lääne-Eestis. ${ }^{2}$ Rahvakunsti all peetakse antud kontekstis silmas eesti ja eestirootsi talurahva kunsti laiemas tähenduses, mis hõlmab nii kujutavat kunsti ja käsitööd kui ka suulist pärimust, laulu ja pillimuusikat, tantsu jne. ${ }^{3}$

Vaadeldakse ajavahemikku alates 1740 . aastatest, mil vennastekoguduse liikumine esimese suurema kristliku usuliikumisena Eestis laiemalt levis, kuni 20. sajandi alguseni, mil 18. ja 19. sajandi talurahvakultuuri muutumise ja ka hääbumise protsess oluliselt kiirenes. Viimase arengu kõrvalpõhjusi ei ole 20. sajandi puhul enam mõtet otsida usuliikumistest. Seda kinnitab juba asjaolu, et alates 20. sajandi alguskümnenditest hakkas erinevate usuliikumiste ja konfessioonide mõju Eesti sekulariseeruvas ühiskonnas üha vähenema, raugedes 
nõukogude perioodil nn laulva revolutsiooni alguseks peaaegu olematuks. Mis muidugi ei tähenda, nagu oleks religioon indiviidide tasandil oma tähtsuse nõukogude ajal samamoodi kaotanud (vt Plaat 2003a).

Käesolevas artiklis ei peatuta luterliku ja õigeusu kiriku suhetel rahvakultuuri ja rahvakunstiga, sest see on täiesti eri teema ja nõuaks eraldi käsitlust. Küll võib aga vennastekoguduse teema sissejuhatuseks väita, et luterliku ja õigeusu kiriku mõju eestlaste ja eestirootslaste rahvakultuurile oli 18. ja 19. sajandil arvatavasti väiksem kui tunduvalt rahvalähedasema vennasteliikumise mõju, seda vähemalt vennastekoguduse liikumisest enam haaratud maakondades.

\section{Vennastekoguduse liikumine}

Vennastekoguduse ehk hernhuutlaste koguduse juured ulatuvad böömi-määri vendade usuliikumisse 15. sajandil. Selle liikumise järeltulijad asutasid 1722. aastal Saksamaal Herrnhutis oma asunduse ja 1727. aastal ka hernhuutlaste koguduse. Vennastekoguduse juhiks ning peamiseks teoloogia ja kommete kujundajaks sai krahv Nikolaus Ludwig von Zinzendorf, kes 1736. aastal külastas Liivi- ja Eestimaad, andes suure tõuke hernhuutlaste edasisele nn Liivimaa tööle. Vennastekoguduse õpetus keskendus Jeesus Kristusele, tema kannatustele ja ristisurmale. Erilist rõhku panid hernhuutlased isiklikule kogemusele Kristusega, vajadusele usuliselt uuesti sündida ehk ärgata. Liikumise üheks peaeesmärgiks saigi tõelise usu äratamine nii nn kombekristlaste kui ka mittekristlaste hulgas. Juba 1730.-1740. aastatel ulatus hernhuutlaste aktiivne misjonitöö peale Euroopa ka Ameerikasse, Aafrikasse ja Aasiasse.

Eesti- ja Liivimaale jõudsid vennasteliikumise põhimõtted alates 1720. aastate lõpust. Aastail 1729-1743 saadeti Herrnhutist Liivi- ja Eestimaale misjonitööle üle 80 hernhuutlasest venna ja õe. Alandlikkust, vagadust ja töökust propageerivad hernhuutlased leidsid peavarju ja tööd hernhuutlusesõbralike mõisnike ja pastorite juures, tavaliselt koduõpetajate, käsitööliste ja arstidena. Kohalikud mõisnikud ja pastorid on saksa hernhuutlasi ka ise kohale kutsunud. Pärast eesti keele omandamist asusid vennastekoguduse misjonärid oma õpetust levitama ka oma valla ja kihelkonna talurahva seas (Sild 1938: 184; Ilja 1995: 43 jj, 53-56, 106).

Vennasteliikumise laiem levik Eesti talurahva seas puhkes 1740.-1741. aastal. 1740. aastate algul võis Eesti alal vennasteliikumisest haaratud olla umbes 10 000-12 000 inimest, sh usuliikumise põhikeskuses Saaremaal koguni 3000-4000 inimest (umbes 25-45\% täiskasvanud talurahvast) (vt Plaat 2001: 36). Koos oma Lääne- ja Hiiumaa usuvendadega moodustasid Saaremaa hern- 
huutlased sellal umbes poole Eesti vennasteliikumises osalenutest. Just sellest perioodist sai alguse Saaremaa, Läänemaa ja Hiiumaa oluliselt suurem vastuvõtlikkus mitmesugustele kristlikele usuliikumistele võrreldes ülejäänud Eestiga. ${ }^{4}$ See käib ka Lääne-Eesti kihelkondades elanud eestirootslaste kohta, ${ }^{5}$ kelle seas olid mitmed usulised äratusliikumised 18. ja 19. sajandil veelgi enam levinud kui Lääne-Eesti eestlaste hulgas. Läänemaalt Vormsi ja Noarootsi kihelkonna rootslaste seast on usuliikumisi kandunud ka eestlaste sekka, aidates vähendada kahe rahvuse vahel eksisteerinud teatavat keeleliskultuurilist barjääri. ${ }^{6}$

Arvatavasti Saaremaal sai vennasteliikumise levides alguse ka vennaste laialdasem võitlus nn paganlike ehk siis hernhuutlaste arvates kristlikele põhimõtetele mittevastavate rahvakultuuriilmingutega. Saaremaal avaldas see võitlus rahva igapäevaelule juba 1740. aastate algul vägagi suurt mõju. Hiljemalt 1741. aastast hakkas Saaremaa usuliikumises rohkelt esinema mitmesuguseid äärmuslikke nähteid. Kerkis esile rahvaprohveteid, kelle eestvedamisel (ja osalt ka saksa hernhuutlaste toetusel) hävitati vanu hiisi ja ohverduskohti, samuti ehteid ja uhkemaid riideid kui patuseid "uhkusasju". Sageli päevi ja öid kestnud palvetundides esines värisemist, mahakukkumist ja liikumatult lebama jäämist. Mõned Saaremaa tüdrukud olevat saanud nägemusi ja ilmutusi ärganute taevas- ja põrguskäimistest, Kristuse verisest kehast või käest, taevasest verevihmast jne. Sellised nägemused olid nähtavasti tingitud hernhuutlastele iseloomulikust vere- ja haavamüstikast, mis oli seotud Kristuse kannatuste ja ristilöömisega. Mõnel pool Saaremaal keelasid kohalikud usuliikumise juhid ka laupäeval ja neljapäeval töötamise (EAA, f 957, n 1, s 1357, 1169 jj; Girgensohn 1869: 453-456; Eckardt 1876: 224-225; Mägi 1999: 104-107). Sellised äärmuslikud nähtused hämmastasid algul ka Saaremaa kirikujuhti superintendent Eberhard Gutsleffi, kellest sai aga peagi kogu saare vennasteliikumise juht ja hiljem üks tuntuimaid märtreid Eesti usuliikumiste ajaloos. $^{7}$

Vägagi üllatavalt tolleaegsetele kirjeldajatele ja hilisematele uurijatele on usuliikumine mõjunud Saaremaa rahva igapäevaelule ja moraaliarusaamadele ning ainelisele kultuurile. Aastakümneid Lääne-Eesti vennasteliikumist juhtinud Saksa hernhuutlase Jacob Marraschi eluloo eestikeelne variant 1894. aastast jutustas sellest järgnevalt:

Suurema hulgal oli tõeste, tõsine nälg ja jänu Jumala sõna ja hinge õnnistuse järele. Ilmlikud lustid, pidud ja kõrtsiskäigud jätsid nemad maha, oma torupillid ja viiulid kautasid ja põletasid nemad ära. Naesterahvas pani oma uhked ehted maha ja hakkasid liht riides käima. Nemad muutsid endid omas elus ja hakkasid üht ilusat viisilist ja korrapäralist elu 
elama. Kõrtsid jäid tühjaks ja kõrtsmikud kaebasid, et nende teenistus viletsa korra peal on. Pulmad, varrud ja matuksed peeti vaiksel viisil. Tantsimise ja prassimise asemel kuuldi laulu ja palve healesid nende majadest kus piduvõerad koos olid. Nad olid hoolsad töötegijad, sõnakuulelikud alamad ning ka hoolsad kiriku-ja armulaual käijad. Aasta 1740 kuni 1745 saadik ei tulnud üht ainust trahviväärilist asja, ega kohtukäimist kohtudes ette (Marrasch 1894: 13).

Liikumise sellist mõju 1740. aastate Saaremaal on rõhutanud paljud teisedki saksa- ja eestikeelsed käsitlused, kus on üksmeelselt kinnitatud, et vennasteliikumine tõi kaasa vaga elu koos pidutsemisest ja kõrtsiskäimisest ning uhketest riietest ja ehetest loobumisega. Eriti rohkelt on hilisemates Eesti kirikuloo- ja ajalookäsitlustes väidetud, et Saaremaal polevat aastatel 1740-1745 esinenud ühtegi kriminaalasja või kriminaalkuritegu. ${ }^{8}$ See väide on siiski arvatavasti ekslik (vt Plaat 2003b: 47-48).

Saaremaa vennasteliikumise puhul on eriti armastatud rõhutada (mõisa)varguse kadumist, mis seni oli talurahva seas suhteliselt laialt levinud. Nii on Saaremaa vennasteliikumise üks fanaatilisimaid juhte ning hiljem selles liikumises osalemise eest vangistatud ja asumisele saadetud Jämaja pastor Franz Hölterhof teatanud, et alates 1741. aastast on usule ärganud Jämaja talupojad varem mõisatest varastatu mõisa tagasi toonud ja mõisnikelt andeks palunud. Kuuldus sellisest enneolematust teost levis kiiresti ja leidis järgimist. Ka mujalt Eestist on teateid, et vennastest talupojad tulid mõisatesse oma endisi mõisavargusi üles tunnistama, samal ajal kui enamik talurahvast ei pidanud seda mitte patuks, vaid nendelt röövitu tagasivõtmiseks (Põldmäe 1979: 69-70; Ilja 2000: 225-228).

Siinkohal tuleb aga silmas pidada, et eeltoodud kirjeldused ja teated Saaremaa rahva moraali ootamatust tõusust tuginevadki enamasti eelnevalt tsiteeritud Jacob Marraschi eluloole, mis allikana on üsna ebausaldusväärne nagu teisedki vennastekoguduse edusamme ülistavad ja hernhuutlaste endi poolt kirja pandud misjonilood. Sellele vaatamata võib aga väita, et koos põrguminemiskartuse laialdase levikuga oli vennastekoguduse levitatavate moraalinõuete mõju 1740. aastate alguse Saaremaal tõepoolest suur, kuid piirdus eeskätt siiski vennasteliikumisest haaratud inimestega. Viimaseid oli aga Saaremaal väga palju.

Võrreldes Saaremaaga esines muu Eesti vennasteliikumises 1740. aastatel mitmesuguseid usufanatismi ilminguid arvatavasti vähem. Nagu massilisemate usuliikumiste algaastatel sageli, tuli seda siiski siin-seal ette, eeskätt Läänemaal (vt Plaat 2001: 34-35) ja Lõuna-Eestis Rõuge kihelkonnas. Viimases tegutses kohaliku talupoja Tallima Paabu juhitud vennastekogudus, kus 
Joonis 1. Jakob Marraschi tõlgitud lauluraamatu tiitelleht. EKLA B-37: 3374.

1740. aastate algul esines rohkelt mitmesuguseid usuekstaasi ilminguid: värisemine, mahakukkumine, hüppamine, kuradi väljaajamine, nägemused jne. Samuti põlati Paabu koguduses luterlikku kirikut ja kooli, luterlikke sakramente ning palveja lauluraamatuid. ${ }^{9}$

Lisaks Saaremaale saab ka muu Eesti puhul tuua näiteid vennasteliikumise hävitavast mõjust traditsioonilisele talurahva kultuurile, eeskätt rahvausundile ${ }^{10}$ ja rahvakunstile (uhkemad riided ja ehted, rahvalaulud ja pillid, tantsud, jutuloome). Mitmes Eesti paigas pidasid hernhuutlased alates 1740. aastatest intensiivset võitlust nn ebausu ja paganlusega seostatava vastu, mida peeti põrgutee sillutajateks. Mõnel pool viis see vanade pühakohtade hävitamiseni, rahvapillide - torupillide, kannelde, sarvede, viiulite purustamiseni, rahvatantsude ja -laulude halvustamiseni. Kõige enam leidub selliseid andmeid siiski 1740. aastate Saaremaa vennasteliikumise kohta.

Arvatavasti olid mitmed Saare- ja Läänemaa äärmuslikumad hernhuutlaste rühmad ja Tallima Paabu kogudus Lõuna-Eestis 1740. aastatel nii luterlikust kirikust kui ka ametlikust vennastekogudusest tegelikult juba eraldunud või eraldumas. Ametlikult jäid kõik talupoegadest hernhuutlased aga luterliku kiriku liikmeteks edasi ka järgnevatel sajanditel. Vastavalt Herrnhuti keskuse põhimõttele jäi vennastekogudus luterliku kiriku sees tegutsema ka aastatel 1743-1817, mil see usuliikumine oli Vene keisririigis keelatud ega tohtinud ametlikult eksisteerida isegi luterliku kiriku raames.

Pärast vennastekoguduse keelustamist 1743. aastal kestis usuliikumine Eesti alal (pool)salaja edasi, eriti tugevalt Saare-, Lääne- ja Hiiumaal (sh ka eestirootslaste seas) aga ka Virumaal, Tallinnas ja mõnes Harjumaa kihelkonnas. Lõuna-Eestis oli vennastekoguduse tegevus keeluajal elavam Võru- ja Tartumaal.

Keeluajal ehitati edasi ka vennastekoguduse palvemaju. Esimesed vennaste palvemajad Lõuna-Eestis olid püstitatud 1740. aastal ja Põhja-Eestis Jüris 1738. aastal, Saaremaal võib-olla veelgi varem (vt Plaat 2003b: 43-44). Vennas- 
tekoguduse palvemajad olid liikumisest haaratud talurahva iseseisvuse väljenduseks. Neid ehitati talurahva vabatahtlike annetuste ning tööjõu abil, millele lisandus vahel ka vennastesõbralike mõisnike ja Herrnhuti keskuse aineline toetus. Osalt on palvemajade ehitamisel järgitud Herrnhutis väljakujunenud mudelit (Philipp 1974: 238jj), kuid otsustades 18. ja 19. sajandil ehitatud palvemajade fotode ja kirjelduste (vt ERM, EA 36: 19-76, 141-261 > E. Põld 1938, 1939) ning väheste tänaseni säilinud palvemajade järgi enamasti siiski kohalikke talurahvaarhitektuuri traditsioone. Näiteks kui ümbruskonna talumajad olid valdavalt rookatusega rehielamud, ehitati ka palvemajad samasugused. Rahvapäraste puitehitistena erinesid need oluliselt luterlikest (ja õigeusu) kivikirikutest. Paljud vennastekoguduse palvemajad olid talurahva arhitektuuri ilusaimad näited, sest palvemaju katsuti ehitada erilise hoolega. Oma palvemajad rajasid ka eestirootslased. ${ }^{11}$

Kuna vennastekogudused tegutsesid keeluajal illegaalselt, leidub antud perioodi kohta teateid liikumise mõjust rahvakunstile jt rahvakultuuri valdkondadele ning rahva igapäevaelule suhteliselt vähe. Tundub, et isegi sellises vennastekeskuses nagu Saaremaa, oli liikumise massilisele algusajale iseloomulik hävitustöö paganalikuks peetud asjade ja nähtuste osas suuremalt jaolt lakanud. Seda hoolimata asjaolust, et 18. sajandi lõpukümnenditel oli vennasteliikumine haaranud taas kogu Saaremaa. Herrnhuti arhiivi andmetel oli Saare- ja Hiiumaal 1801. aastal kokku 4422 vennastekoguduse liiget. ${ }^{12}$ See teeb umbes $11 \%$ sealsest talurahvast. Neile lisandusid veel palvetunde külastanud mitteliikmed (vennastekogudusse vastuvõtmisel järgiti küllalt rangeid nõudeid kandidaadile ja sugugi kõik palvetundides käijad ei saanud kohe koguduse liikmeteks).

Kuigi aastatel 1747-1792 Lääne-Eestis suure eduga tegutsenud saksa hernhuutlase Jakob Marraschi ja tema poolehoidjate teeneks võib lugeda mitmeid jätkuvaid muutusi saarlaste moraaliarusaamades ja igapäevaelus, ei kadunud joomine, varastamine ja muud patuks loetud nähtused Saaremaa vennasteliikumise keskustes ka 18. sajandi lõpukümnenditel, isegi mitte vennastekoguduse liikmete seas, nagu selgub J. Marraschi Herrnhuti saadetud aruannetest (vt Mägi 1999: 89-90). J. Marrasch kirjutas pidevalt vennastekoguduse võitlusest talurahva pattudega. Nii kirjeldas ta rannaalade, eriti Saaremaa vennasteliikumise toonase põhikeskuse Kihelkonna rahva varastamist ja riisumist laevahukkude puhul. Kihelkonnas olevat hakanud see komme tänu vennaste pingutustele kaduma 1780. aastatel. See oli aeg, mil kihelkonda kerkis lühikese ajaga tervelt kuus hernhuutlaste palvemaja. Kuid 1790. aastatel valitsesid merel suured tormid ja neile järgnenud laevahukud tõmbasid ka kõige usklikumad talupojad taas kiusatusse (Põldmäe 1940b: 79). Võib arvata, et J. Marraschi suhtumine hukkunud laevade riisumisse oli ka hoopis teine kui põlisel 
rannarahval, kes on läbi aegade saanud hukkunud laevadelt vajalikku ehitusmaterjali ja muud tarvilikku.

Andmeid varastamisest ja joomisest vennastekoguduse liikmete seas leidub mujaltki Eestist. Nii on Saksa hernhuutlane J. C. Schreiber kirjutanud 1818. aastal, et Hiiumaal kaldusid ühe palvemaja vennad joomisele ja olevat merehädalisi röövinud (Põldmäe 1958: 427-429).

Seega oli vennasteliikumise mõju rahva moraaliarusaamadele ja igapäevaelule isegi peamistes liikumise keskustes sageli üsna lühiajaline. Siiski võib nõustuda mitme autoriga, kes on kogu Eesti vennasteliikumise puhul esile tõstnud vennaste askeesi ja kõrgeid moraalinõudeid, mis väljendusid varastamisest loobumises, maistest lõbudest keeldumises, alkoholi ja tubaka eitamises, kaklemisest loobumises. Osa hernhuutlasi polevat ka tantsinud ega söönud käkki ja verivorsti. Alkoholi eitamine viis aga mitmetes vennastekeskustes kõrtside sulgemiseni ${ }^{13}$ (Sild 1928: 103; 1934: 67; Põldmäe 1938a 281-282; 1965: 221; Veiderma 1969: 50). Neid tendentse ei maksa aga laiendada liikumisest haaratud piirkondade talurahvale tervikuna, piirduda tuleks ikkagi vennasteliikumisest otseselt haaratud inimestega. Arvatavasti just see asjaolu on päästnud liikumiskeskustes täielikust hävingust ka teatud patuseks loetud rahvakunstiesemed.

Külarahva suhtumise ja elulaadi täieliku muutmise asemel võib isegi liikumise põhikeskustes rääkida pigem vaheseina tekkimisest vennastekogudusse kuulunute ja mittekuulunute vahel. Lõhe tekitamisega "usklike" ja "uskmatute" vahele loodi külaühiskonnas nagu kaks eri maailma, millevahelise piiri kehtestas "tõelisele" usule ärkamine või mitteärkamine. Süüd selle lõhe tekkimises oli nähtavasti mõlemal poolel.

Mis puutub aga vennasteliikumise algusaegadel, 1740. aastate esimesel poolel toimunud rahvariiete, ehete ja pillide hävitamisse ning rahvatantsude põlu alla panekusse, siis on hernhuutlaste kristlik-vagatseva maailmavaate negatiivne mõju rahvakunstile ilmne, eriti sellistes keskustes nagu Saare-, Lääneja Hiiumaa. Rahvakunsti laastamine kaasnes usuliikumistega ka hiljem, eriti teravas vormis vennastekogudustega seotud nn taevaskäijate liikumise raames.

\section{Taevaskäijate liikumine}

Erinevates usundites tuntud taevas- ja põrguskäimise motiiv ${ }^{\mathbf{1 4}}$ sai eestlaste ja Läänemaa eestirootslaste usuelus eriti populaarseks alates 1813.-1814. aastast, mil uus usuliikumine puhkes kõigepealt Virumaal ja Läänemaal. Mitme prohveti uudsed kuulutused levisid seal kulutulena, edendades suuresti ka 
vennasteliikumist. Järgneva aastakümne jooksul levis taevaskäijate (ka nõrkujate, õnnistegija laste) liikumine kogu Eestis, eriti Lääne- ja Harjumaal, kus peaaegu igas kihelkonnas olid oma taevaskäijad. Laiemalt levis liikumine veel Tallinna kandis ning Viru-, Tartu- ja Viljandimaal. ${ }^{15}$

Enamasti olid taevaskäijad tüdrukud ja naised, kes said kas magades, meelemärkuseta olekus või siis nõrkevas-värisevas ekstaasiseisundis nägemusi taevast ja põrgust, kus nad väitsid end käinud olevat. Seejuures meenutasid taevaskäijate kirjeldused taevast ja põrgust koos sealsete asukatega selgelt talupoeglikku miljööd maa peal. ${ }^{16}$ Saadud ilmutuste põhjal jutustati, keda elavatest või surnutest on nähtud taevas, keda põrgus, ja ennustati inimestele selle põhjal nende saatust pärast surma. Taevaskäijad ja nende poolehoidjad tegelesid aktiivse usukuulutamisega, kutsusid meeleparandusele, pidasid palvekoosolekuid ja ennustasid prohvetlikult. Paljudes kohtades hakati kuulutama ja ootama maailma lõppu, mõned taevaskäijad on kuulutanud end ka lunastajaks või imetegijaks (Sild 1938: 196).

Käesoleva artikli seisukohalt on selle usuliikumise puhul huvitav asjaolu, et taas võttis maad selline 1740. aastatel levinud nähtus nagu nn uhkusasjade hävitamine. Järgnevalt paar näidet peamistest taevaskäijate liikumise keskustest Lääne- ja Hiiumaalt, kus taas osalesid eestlaste kõrval uudses liikumises ka eestirootslased.

1815. aastal põletasid eestlased ja rootslased Nõva küla 9-aastase taevaskäija prohvetlikke tulevase elu kujutlusi ja manitsusi uskudes oma ehteid ja uhkemaid riideid, eriti kirjusid põllesid, punaseid rätte, kollaseid juuksepaelu ning hõbedasi kaelakette ja sõlgi. Osa ehetest olevat müüdud ka naeruväärse hinna eest juutidele ning edaspidi nähtud Nõva kandis vaid musti ja valgeid rätikuid (Russwurm 1855: 235-236; Põldmäe 1935: 154).

Hernhuutlane Carl Heinrich Werner nägi 1816. aastal Noarootsi kihelkonnas Niibi kandis tegutsenud prohvetit, kellele Jumal olevat taevas teatanud peatsest maailmalõpust. Rahvas pidi selleks valmistuma muuhulgas ka oma uhkema vara põletamisega. Kes ei tahtnud põrgusse minna, pidi prohveti käsul loobuma hõbeehetest ja kõigist värvilistest riideesemetest, eriti punase- ja sinisevärvilistest. Seejuures ei tohtinud neid ära müüa või kinkida, vaid pidi põletama. Taevaskäija kuulutus olevat levinud kulutulena vallast valda ning rahvas olevat püstitanud tuleriitu, kus oma maine vara, enamasti hõbeesemed, paelad, mütsid, põlled, rätikud, seelikud jms rõõmu ja pidulikkusega tulle visati, nii et paari päevaga olnud enamik inimestest puupaljad. Ehkki Läänemaal tegutsenud saksa hernhuutlased olid üldjuhul "taevaskäimise" ja oma vara hävitamise vastu, osalesid hävitustöös ka Niibi vennastekoguduse juhid ja liikmed (Põldmäe 1958: 457-459). 
Taevaskäijate liikumise kohati massilisest levikust annab tunnistust asjaolu, et ainuüksi Hiiumaal olevat peale nelja kuulsaima taevaskäijast naisprohveti tegelnud 1817. aasta paiku ennustamisega veel koguni 30 naist ja kaks poissi. Hiiumaa taevaskäijad olevat sooritanud ka uut ristimist suitsu ja tulega ning omalaadset armulauda mingi uimastava joogi jagamisega (Sild 1935: 110). Vaatamata suurele levikule paljudes Eesti maakondades vaibus taevaskäijate liikumine 1820. aastate algul, paljuski aitasid sellele kaasa ilmalike ja kiriklike võimude repressioonid. ${ }^{17}$

Tunduvalt tasakaalukam vennasteliikumine (või selle peavool) kosus aga jõudsalt edasi, eriti pärast vennastekogudustele tegevusloa andmist 1817. aastal.

Eesti vennasteliikumise ajaloo suurima koguduseliikmete arvuni jõuti 1850. aastate keskpaigaks, mil 50531 vennastekoguduse liiget moodustasid ligikaudu 6,7\% Eesti ala elanikkonnast (Philipp 1974: 219-220). Koos palvetunde külastanud, kuid kogudustesse (seni) mitte vastuvõetud inimestega oli see arv oluliselt suuremgi.

Mitmel põhjusel algas aga 19. sajandi keskpaigast vennasteliikumise kiire allakäik. Eestimaa kubermangus (Põhja-Eestis) olid vennastekogudused 19. sajandi teisel poolel veel suhteliselt elujõulised, Lõuna-Eesti mandriosas oli aga 20. sajandi alguseks hernhuutlus peaaegu välja surnud (vt lähemalt Plaat 2001: 48-49, 138-140). Vaatamata vennasteliikumise taandumisele jätkasid allesjäänud hernhuutlased oma võitlust mitmete nn patuste rahvakultuuri ilmingute, näiteks ilmalike "laululorade" ja "tühjade juttude", samuti nende kogumise vastu rahvusliku ärkamisliikumise kõrgajal 1870.-1880. aastatel. Lääne-Eestis on neile selles tegevuses appi tulnud 19. sajandi lõpuveerandi usuliikumistes osalenud.

\section{Läänemaa usuline ärkamisliikumine ja uued vabakogudused (priilased, baptistid, irvinglased jt)}

1870. aastate teisel poolel puhkes Läänemaa eestirootslaste seas ja seejärel ka kõigis Läänemaa eestlaste kihelkondades nn Läänemaa ärkamine ehk usuline ärkamisliikumine, mis jagunes oma arengus 1880. aastatel mitmeks eraldi vooluks ja liikumiseks, sh priilaste, irvinglaste ja baptistide usuliikumiseks.

Noarootsi koolitööle siirdunud Rootsi misjonäri Thure Emanuel Thoréni ja tema ametivenna, Vormsile õpetajaks läinud Lars Johan Österblomi kuulutustegevuse tulemusena algas uus usuliikumine. Tänu T. E. Thoréni ja tema õpilaste pingutustele levis usule ärkamine aastateks 1877-1878 terves Noa- 
rootsi kihelkonnas. Usuliikumine mõjus tugevasti rahva kõlbelistele arusaamadele: paljud külakõrtsid jäid tühjaks, põrguhirmus talurahvas hülgas viina, suitsetamise ja tantsimise. Thoréni arvates võis tema karskusepropaganda tulemuseks olla Noarootsi seitsme kõrtsi sulgemine ostjate puudusel (EBKAA 1911: 120-121; Tuttar \& Dahl 1929: 104; Kaups 1974: 19).

Veelgi hämmastavamalt muutis usuäratus Vormsi rootslaste elu. 1873. aastal saarele saabunud misjonäri L. J. Österblomi töö tulemusena haaras "Vormsiusule" ärkamine 1870. aastate teisel poolel kogu saare. L. J. Österblomi enda mälestuste (Österblom 1927) ja nendele toetuvate käsitluste järgi olevat saarelt peaaegu täielikult kadunud joomine ja suitsetamine, mitmed külakonnad olevat oma piibud avalikult maha matnud. Kadunud olevat ka vägisõnade tarvitamine, varastamine (ka mõisa valdustest) ja vähenenud muudki patud. Patuseks pidas L. J. Österblom aga ka rahvalaule ja -tantse ning värvikirevaid rahvarõivaid. Kuigi L. J. Österblomi mälestustes on arvatavasti ärkamisliikumise tulemusi ilustatud, levis paljuski tänu tema pingutustele saarel lugemisja kirjaoskus, uudsed arusaamad hügieenist ja tervishoiust, ning me ei pruugi kahelda usuliikumise väga suures mõjus vormsilaste igapäevaelule. Nii näiteks võib uskuda L. J. Österblomi väidet, et usuliikumise tulemusena suleti saare kõik 13 kõrtsi.

Selle teate usaldusväärsust tõstab eestirootsi kiriku- ja kultuuritegelase Hjalmar Pöhli kinnitus, et hiljemgi valitses Vormsil kohalik alkoholijookide müügikeeld (Pöhl 1949: 175). Vormsi ärkamise soodsat mõju rahva elule on rõhutanud enamik riigi- või eestirootslastest autoreid, pannes aga L. J. Österblomile kohati pahaks vanade rahvakommete väljatõrjumist ja Vormsi rootslaste rahvustunde nõrgenemist. Rootsi misjonäride eesmärgiks oli ärganute vendadeks-õdedeks saamine, olgu nad siis eestlased või rootslased, põhimõttel rahvuslik taganegu usulise ees (Danell 1909: 29; Wennerström 1931: 272; Valentin 1938; Danell 1999: 124-127).

Kõigisse Läänemaa eestlaste kihelkondadesse, seejärel Hiiumaale ning mitmesse Pärnu- ja Harjumaa kihelkonda levis uus usuliikumine paljuski tänu enamiku ärkamiskeskuste luteri pastorite esialgsele toetusele 1870.-80. aastate vahetuse paiku. Veel 1879.-1880. aastal on Läänemaa kirikuõpetajad tunnustanud ärkamise järgseid puupüsti täis kirikuid (algul käisid ärganud lisaks oma palvetundidele ka luterlikel jumalateenistustel), jumalasõna ja palvetamise äkilist aussetõusmist, talurahva püüdu aususele, õiglusele ja rahuarmastusele, joomarluse kadumist jne (Schultz 1880: 583-584).

Viinajoomise aga ka uhkemate rõivaste kandmise keeld on tõepoolest kiirelt levinud eestirootslaste kihelkondadest eestlaste sekka. Üks liikumises osalenu meenutas 1870. aastate lõpust järgnevat: 
Kõrtsid olid inimestest tühjad. Üks suurematest kõrtsipidajatest avaldas kord, et ta kahe kuu jooksul ainult ühe kortli viina mü̈̈nud. Kodune viina tagavara sai ärahävitatud. Mitmed olid oma möödaläinud elu pärast nii maharõhutud, et lihtsaid riideid kandsid ja uhkemad hilbud enestest eemale hoidsid. Vanad inimesed õppisid suure hoole ja isuga lugema ja laulma [---] (KPL 1930 (3): 66).

Usuliikumise mõju rahva kommetele sõltus palju kohalike eestvedajate arusaamadest. Kuivõrd erinev võis ärkamisliikumise keskustes olla suhtumine mõnda nähtusse, demonstreerib ärganute suhe tantsimisse. Misjonär Thure Emanuel Thorén olevat tantsimist tauninud, mille tõttu olevat Noarootsi ärganud sellest loobunud (Busch 1928: 12, 15; Tuttar \& Dahl 1929: 104). Läänemaa Ridala palvekoosolekutel olevat aga T. E. Thoréni ja L. J. Österblomi toodud uued rootsi laulud ajanud ärganuid lausa tantsuekstaasi:

Rootsi=trallisid lauldes tõstetakse seda=jalga ja tõist jalga ja keerutatakse ratasringi, kõigutakse ja väentakse pääd, lü̈̈akse lahtise käega vasta silmi mis plaksub, kistakse juuksed palmikust lahti, pillatakse päärätid jalge alla, ja hüpatakse mittu tundi ühteotsa pidi, olgu koht tüma ehk kõva (EKLA, f 47, m 41:33, 1 1/7).

Aeglased ja unised kirikuviisid polevat aga ärganute meelest kuhugi kõlvanud.

Samalaadsest tantsimisest on teateid ka Kullamaalt, Vormsilt ja Hiiumaalt (EKLA, f 200, m 3:2, l 102-103; Valgus 1884 (5): 2; EAA, f 29, n 2, s 5355, 1 56; Normann 1885: 109). Mõnel ärganute koosolekul olevat aga tantsitud paarikaupa:

Kaks- kuni kolmkümmend paari olid korraga põrandal keerutamas, nurgas olijad aga hüppasid, käsi kokku lü̈̈es ja valju häälega hõisates, ülespidi (KPL 1930 (6): 130).

Nii meenutas üks ärganuid liikumise algusaegu.

Tantsimiseks kasutatud Rootsi misjonäride uued nn rootsi laulud olid religioosse sisuga, nende saateks kasutati vähemalt usuliikumise algul sageli lõbusaid ja kiireid viise, tihti polka taktis (nn Rootsi trallid ja tantsutükid). Uusi "rootsi laule" lauldi enamikus ärkamiskeskustes, ka töö juures või teel olles, samuti Haapsalu tänavatel (EPm 1881 (29): 114; EKLA, f 47, m 41:33, 1 1/7). Need uued religioosse sisuga laulud ja vanade laulude halvustamine usuliikujate poolt aitasid Läänemaal nähtavasti oluliselt kaasa vana rahvalaulu väljatõrjumisele. Sama võib kogu Eesti ulatuses öelda ka vennasteliikumise rikkaliku laululoome kohta. 
Võib öelda, et Läänemaa algse ärkamisliikumise levik ja laad erines paikkonniti tugevasti, suunates mõnes usuliikumiskeskuses (eriti eestirootslaste ja rannikukihelkondades) tugevasti rahva elulaadi ja kombeid. Peaaegu igal pool tekkis aga vastuolusid ärganute ja mitteärganute vahel, kusjuures mõlemad pooled kippusid süüdistama üksteist patuelus. Palju süüdistati nn uueusulisi näiteks mitmesuguste seksuaalriituste läbiviimises ja abielurikkumistes (vt Plaat 2001: 321-323; Plaat 2003b: 106-109). Teravaks kujunes usuliikujate vahekord ka võimudega, eriti pärast seda, kui liikumises üha süvenevad äärmuslikud nähtused muutsid enamiku luteri pastorite esialgse soosiva suhtumise vastupidiseks.

Pärast luterliku kiriku ja ilmalike võimudega vastuollu sattumist arenesid ärkamisliikumisest 1880. aastatel välja eri voolud: tegutsemisloaga irvinglaste ja baptistide ning illegaalsed priilaste kogudused. Osa jätkas oma tegevust luterlikule kirikule truuks jäänud vennastekoguduste raames. Teatud hulk ärganuid siirdus 1880. aastatel aga hoopis õigeusu kirikusse. Nähtavasti ootamatuim sündmus oli veerandi Vormsi rootslaste siirdumine vene õigeusku vähem kui nädala jooksul, seda hoolimata keelelisest ja kultuurilisest barjäärist, mida õigeusu kirikul ei õnnestunudki Vormsil ületada (vt Plaat 1999).

Nimetatud uued kogudused ja liikumised levisid vähemal määral mujalgi Eestis aga eeskätt mõjutasid need Lääne-Eesti usuelu ning seeläbi ka sealsete eestlaste ja eestirootslaste rahvakultuuri.

\section{9. sajandi lõpuveerandi ja 20. sajandi alguse usuliikumiste mõju eestlaste ja eestirootslaste rahvakultuurile}

Lääne- ja Hiiumaa usuliikumiste tulemusena moodustatud esimestes Eesti vabakogudustes (baptistid, priiusulised, irvinglased, pärast usuliikumise levikut Saaremaale 20. sajandi algul ka metodistid jt) jätkus paljuski vennasteliikumisega alguse saanud rahvapärane usutraditsioon, mh ka teatud vaenulik suhtumine talurahvakultuuri teatud valdkondadesse. Kogu Eestis jätkus 19. sajandi lõpuveerandil ja 20. sajandi algul ka allesjäänud vennastekoguduste võitlus vana rahvakultuuriga.

Sellele võitlusele on negatiivse hinnangu andnud mitmed Eesti rahvaluule kogujad, folkloristid ja usundiloolased. Alates 1888. aastast kogu Eestis mastaapset rahvaluule kogumist juhtinud Jakob Hurt märkis, et tema kogumistööle oli kõige suuremaks takistuseks mõnes kohas iseäraline kitsasüdamega pietismus (vagaduse ilmutus), mis kõiki vanu laulusid, muinasjuttusid, kom- 
beid ja pruukisid, muidugi iseäranis kõiki vanu rahva uskumisi patuks arvab ja juba ette halastamata hukka mõistes neid saatana töö nimega nagu märkrauaga ära tähendab (Olevik 1896 (50): 113).

Eriti võis sellist suhtumist märgata vennasteliikumise keskustes ja usuliikumistest haaratud Läänemaal.

Rudolf Põldmäe väitel on rahvaluulet kõige vähem kogutud just Läänemaalt ja usuliikumiste mõjul on seal regivärsiline rahvalaul kiiremini kadunud kui mujal Eestis. Ühe rahvaluulekoguja 1894. aastal antud hinnangul olevat lahkusuliste lauluraamatud hävitanud Ranna-Läänemaal rahvalaulu. Laastavalt mõjusid usuliikumised ka rahvakommetele. Lisaks on usule ärganud otseselt takistanud rahvaluulekogujate ("kuraditeenrite") tööd (vt Põldmäe 1959: 412-415; Veiderma 1969: 50, Jansen 1977: 115-116). Jakob Hurdale kaastööd teinud A. Suurkask kirjeldas olukorda Läänemaal 1896. aastal järgnevalt:

Kui aga juba lugejad rahva sekka ilmusivad, kes palvemajades rahvale lihtsalt ja arusaadavalt nende ristiusku ära seletasivad ja näitasivad, kui suurt pattu nad sellega jumala ees teevad, et nad veel endise paganausu kombeid kinni peavad, rumalaid rahva lorilaulusid laulavad ja ennemuistseid vanapaganate jutte räägivad j.n.e. Sellega sai siis küll rahvas usu poolt äratatud, kuid hulgale ilusatele rahvalauludele ja muinasjuttudele tõi see külma surmahaua. [---] Niisuguse maanukkades nagu Läänemaal, kus "lugija rahvas" on, ei ole vanavara leida (tsiteeritud Põldmäe 1959: 412-413 kaudu).

Väide, et nn vanavara 19. sajandi lõpuks Läänemaal leida ei olnud, on mõistagi liialdus. Kindlasti leidus rohkelt ka usuliikumistes mitteosalenud inimesi, kes teadsid vanu laule ja uskumusi. Samas ei tahtnud neistki paljud sellist pärimust edasi anda, pidades seda toonasel Lääne- ja Hiiumaal laialt levinud arusaama kohaselt patuks. Samalaadsete probleemidega põrkusid rahvaluule kogujad kokku ka mujal Eestis, kuigi vähem kui Lääne- ja Hiiumaal.

Seejuures tuleb arvestada, et sellist mõju ei avaldanud Lääne- ja Hiiumaal rahvaluulele ja -usundile mitte ainult 19. sajandi lõpuveerandi (ja Saaremaa 20. sajandi alguse) usuliikumised, vaid ka varasem vennastekoguduse liikumine, mis juba alates 1740. aastatest oli Lääne-Eestis kõige levinum. Ka 20. sajandi alguskümnenditel oli vennasteliikumine Saare-, Lääne- ja Hiiumaal elujõulisimaid Eestis.

Folkloristi ja usundiloolase Oskar Looritsa ilmselt liialdatud arvamuse järgi domineeris Läänemaal ja saartel hernhuutlus nii põhjalikult, et ruineeris seal osaliselt vana rahvalaulu ja lagastas isegi juturepertuaari, asendades neid palvete, vaimulike laulude ja suuri rahvahulki liikumapanevate "prohvetitega", kes eluajal juba muutusid mütoloogilisiks (Loorits 1932: 39). ${ }^{18}$ 
Rudolf Põldmäe on väitnud, et Lääne-Eestis ja saartel, kus veel 1930. aastatel võis avastada terveid külasid fanaatilisemaid lahkusulisi, leidub rohkelt lugusid prohvetitest, taevaskäijatest, ilmutustest, vaimudest ja üldse kõigest üleloomulikust (Põldmäe 1938b: 439).

Uskumustega seotud rahvapärimuse üks levinuimaid vorme Lääne- ja Hiiumaal ongi nn prohvetilood. Neid jutustati nii usuliikumistes osalenud rahvaprohvetitest kui ka käesolevas artiklis käsitletud usuliikumistega otseselt mitteseotud prohvetitest. ${ }^{19}$ Viimastest on kuulsaimad 19. sajandi esimesel poolel Lääne- ja Pärnumaal ennustajatena tegutsenud Järve Jaan ja Jaagori Jaan (nende kohta vt lähemalt Eisen 1921; Masso 1928), kelle prohvetikuulsus süvenes eriti pärast nende surma.

Jutud prohvetitest, taevaskäijatest, ärganutest ja nn lugejatest (s.t palvemajade jutlustajatest ja koguduste liikmetest), samuti religioosse sisuga laulurepertuaar ei olnud Lääne-Eestis mitte ainult usuliikumiste tulemuseks, vaid need mõjutasid ka kohaliku talurahva maailmavaadet ja koos sellega suhtumist nn paganlikku rahvakultuuri (sh rahvakunsti eri vormidesse), pannes aluse suuremale vastuvõtlikkusele uute usuliikumiste ja usu suhtes üldse.

Kuna Lääne-Eestis oli usuliikumistest haaratud siiski väiksem osa talurahvast, ei saa seda väidet muidugi laiendada kõigile. Sealses rahvaluules leidub rohkelt näiteid ka usuliikujate ja prohvetite naeruvääristamisest, samuti pole säästetud pastoreid ega luterlikku kirikut (vt KPSL 1963). Ilmselt levinumaks žanriks kui vagatsevad jutud, olid usuliikumistega mitteseotud inimeste seas hoopis pilalood usuhulludest ja hüppajatest (palvetundides tihti esinenud ekstaatilise hüppamise tõttu oli viimane termin rahvasuus ja ajakirjanduses 1870.-1880. aastatel üks levinuimaid).

Tuleb rõhutada, et Lääne-Eestis levinud usuliikumised ei suutnud vanemat rahvalaulu ja juturepertuaari täiesti välja tõrjuda, samuti mitte vanemaid rahvauskumusi ja kombeid. Piiblitarkusega segatud rahvauskumuste motiivid säilisid ka muidu rahvaloomingusse vaenulikult suhtunud usklike seas, segunedes uuema usulise taustaga rahvaloomega.

19. sajandi lõpuveerandi usuliste ärkamisliikumiste võitlus rahvakunsti jt rahvakultuuri valdkondadega on olnud väga edukas vaid teatud usuliikumiskeskustes ja eriti eestirootslaste kihelkondades. Ja sealgi pole sellelaadne mõju olnud alati püsiv. Näitena sobib siia Vormsi saar. Lars Johan Österblomi jt usuliikumise eestvedajate võitlus rahvalaulu, -tantsu, -pillide ja -rõivaste vastu Vormsil 1870.-1880. aastatel jättis aastakümneteks jälje vormsilaste rahvakunstile. Vormsit 20. sajandi alguskümnendil mitu korda külastanud Nikolai Arepjevi järgi kadus Vormsi naiste värvikirev rahvarõivas suures osas alates L. J. Österblomi saabumisest 1870. aastatel. 20. sajandi alguses olevat vormsi- 
laste rõivad olnud enamasti väga tagasihoidlikud ja ilma eheteta. ${ }^{20}$ Ometi ei onnestunud Vormsi naiste värvikirevate rahvariiete väljatõrjumine usumeestel lõplikult. Mitme kirjeldaja andmed 1920.-1930. aastatest kinnitavad, et erinevalt meestest käisid peaaegu kõik Vormsi naised nii argi- kui pühapäeval taas peamiselt endavalmistatud värvikirevates rahvarõivastes. ${ }^{21}$ Et L. J. Österblomi ja usuliikumiste mõju Vormsi naiste rahvarõivastele polnud sugugi nii suur või vähemalt mitte nii pikaajaline kui sageli arvatud, kinnitavad ka fotod vormsilastest 1920.-1930. aastatel.

Sarnaselt on aja jooksul muutunud ka usklike arvamus rahvamuusikast ja -pillidest. Vormsi näidet jätkates on osa rahvalikest pillidest Vormsi usklike poolt alates 1870. aastatest tõepoolest hävitatud (eelkõige torupillid ja hiiu kandled), kuid 20. sajandi algul ja Eesti Vabariigi ajal kasutati Vormsi palvetundides vaimuliku koorilaulu saateks kitarre, tsitreid, kandleid, viiuleid ja mandoliine (ERM, TAp 205: 10-13 < H. Halliste 1920; Zassetskaja 1998: 105106). Seevastu tantsimist ja ringmänge on ühe kirjelduse järgi Vormsil veel 1930. aastate algul patuks arvatud ja isegi pulmi olevat peetud ilma tantsuta. Taas ei kehti see väide aga kõigi vormsilaste kohta. Nii olevat osa vanemaid vormsilasi pidanud Sviby küla põlemise põhjuseks seda, et seal palju tantsiti (Meie Maa, nr 121, 1932, lk 3).

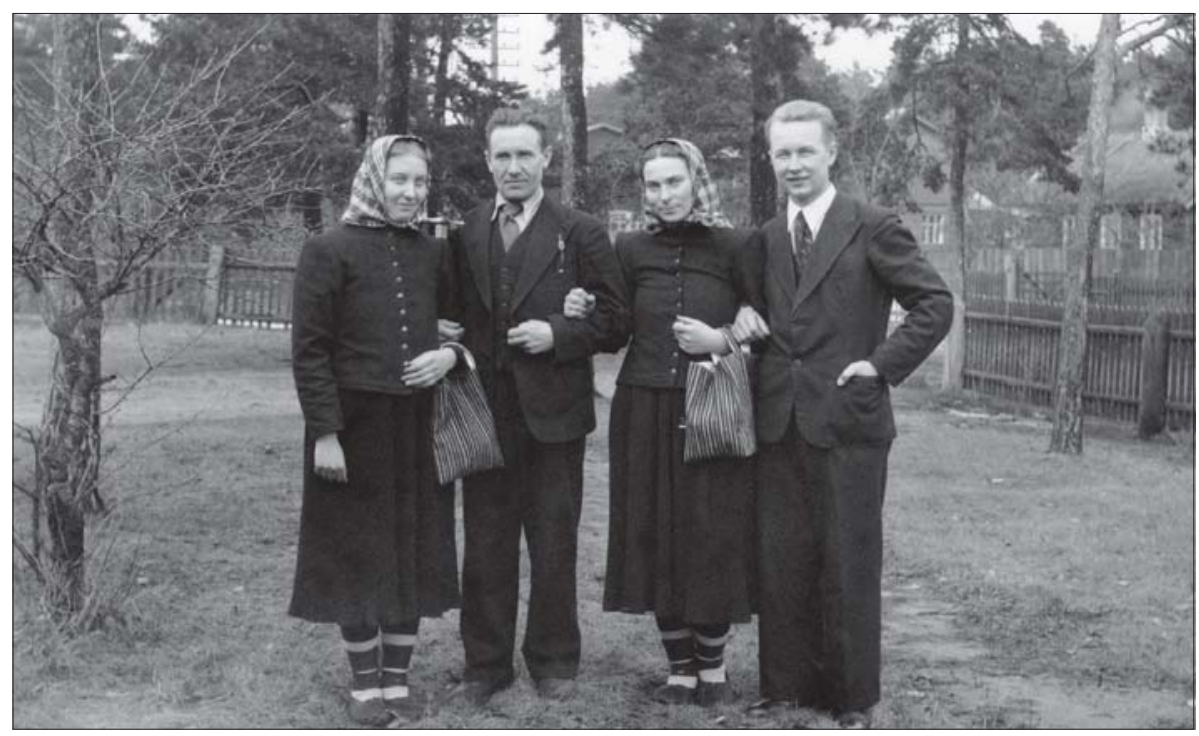

Foto 1. Nagu näha 11. juulil 1939. aastal Helga Võigemasti tehtud fotolt, pole toredust põlgavad usuliikumised suutnud Vormsi naisterõivastusest jäägitult värve välja tõrjuda: kirju rätik, oranžid sukad, ja käevarrel kantav särav triibukott ergastavad tõhusalt tumedat rõivastust. EKLA A 31:330. 
Peale Lääne- ja Hiiumaa, pole mujalt Eestist 19. sajandi lõpul ja 20. sajandi algul enam laekunud andmeid usuliikujate otsesest hävitustööst nn uhkusasjade, rahvariiete ja rahvalike muusikariistade kallal. Seda juba põhjusel, et tol ajal levisid usulised ärkamisliikumised massilisemalt veel üksnes Lääne- ja Hiiumaal ning 20. sajandi algul Saaremaal. Siiski ei toonud need usuliikumised Lääne-Eestis enam kaasa selliseid muutusi rahva igapäevaelus ning uskumustes nagu vennasteliikumise algusaegadel ja taevaskäijate liikumise ajal. Isegi nn ebausk ehk vanemad rahvauskumused ja nendega seotud kombed olid vaatamata usuliikujate pingutustele usulise ärkamisliikumise aegsel Läänemaal visad taanduma. ${ }^{22}$ Seda hoolimata asjaolust, et usulised ärkamisliikumised olid 18. ja 19. sajandil võitluses rahvausundiga enamasti edukamad kui luterlik kirik, mis samuti on pidevalt püüdnud võidelda talurahva mittekristlike uskumuste vastu.

Hoolimata eelpool esitatud rahvaluulekogujate väidetest on vanad rahvauskumused Lääne-Eestis edasi elanud ka 20. sajandi esimestel kümnenditel, kuigi üha enam on hakatud pidama neid väljamõeldisteks. Eriti eakamate inimeste uskumustes oli vana usundi elemente Lääne- ja Hiiumaal alles veel 1930. aastatelgi. Seejuures olnud just seal pühade kivide, allikate ja puude kultus Eestis kõige paremini säilinud. Rannikukihelkondades olid elujõus veel kalastusega seotud uskumused (vt Läänemaa 1938: 143-145). Üldjoontes võib sama väita ka Saaremaa kohta (vt lähemalt Plaat 2003b: 40-41).

Seega on Lääne-Eestis ka pärast suuremaid usulisi ärkamisliikumisi edasi elanud rahvausund, eeskätt usk nõidusesse, deemonlikesse surnutesse (kodukäijad), haldjatesse ja pühakohtadesse. See on kohati segunenud erinevate kristlike konfessioonide levitatud õpetuste ja kommetega. Omalaadne segu kristlusest ja vanast rahvausundist on end tunda andnud mitme kristliku usuliikumise eestvedaja juures, seda nii vennaste ja taevaskäijate liikumise kui ka Läänemaa ärkamisliikumise ja sellest väljakasvanud vabakoguduste raames.

\section{Kokkuvõte}

Eelnevalt on toodud mitmeid näiteid osa 18. ja 19. sajandi usuliikujate kristlik-vagatseva maailmavaate negatiivsest mõjust rahvakultuurile, sh rahvakunstile. Näiteks nn uhkusasjadest ehk värvikirevamatest riietest ja ehetest loobumisest või isegi hävitamisest on andmeid nii 1740. aastate vennasteliikumisest, taevaskäijate liikumisest kui ka 1870. aastatel puhkenud Läänemaa ärkamisliikumisest. Eriti sageli on nn uhkusasjade hävitamist esinenud Lääne- 
Eesti maakondades. Üle-Eestilise levikuga vennasteliikumise puhul pärinevad teated sellisest hävitustööst veel teisest suuremast vennastekeskusest KaguEestist, jäädes siiski pigem üksikjuhtudeks (Jansen 1987: 199). Samuti on vennasteliikumine ja sellele järgnenud usulised ärkamisliikumised olnud paiguti edukad rahvausundi ja rahvaluule teatud valdkondade väljatõrjumisel.

18. ja 19. sajandi kristlike usuliikumiste täielikust hävitustööst rahvausundi ja rahvaluule suhtes pole aga õige rääkida. Samuti on üldjuhul liialdatud väited mõne paikkonna usuliikujate täielikust võidust rahvaliku muusika ja pillide, käsitöö (eriti riiete ja ehete), tantsude jt rahvakunsti väljendusvormide üle erinevate usuliikumiste kõrgperioodidel. Käsitletud usuliikumiste tugevat mõju rahvakultuuri teatud valdkondadele pole aga põhjust eitada, eriti Lääne-Eestis.

Nii vennaste, taevaskäijate kui ka 19. sajandi lõpuveerandi usuliikumisi iseloomustas teatav asketism ja kõrgete moraalinõuete esitamine. Siiski piirdus nimetatud usuliikumiste sellelaadne mõju eeskätt usklikega ega levinud kogu külaühiskonnas. Suurem muutus rahva senistes tõekspidamistes ja elulaadis toimus taas Saare-, Lääne- ja Hiiumaal ning eriti märgatavalt eestirootslaste kihelkondades.

Kui vana rahvakultuuri väljendusvormide halvustamist ja hävitamist võib vähemalt enamiku antropoloogide/etnoloogide ja folkloristide arvates pidada negatiivseks, siis käsitletud usuliikumiste puhul võib tuua esile ka palju positiivset (ehkki sellistest hinnangutest võib olla targem üldse loobuda). 18. ja 19. sajandil levinud uued usuühendused rajasid Eestis rahvapärase kristliku usuliikumise traditsiooni, mis jätkus ka 20. sajandi vabakogudustes. See vennasteliikumisega alguse saanud usutraditsioon on edukalt rahuldanud nende inimeste vajadusi, kellele ei piisanud luterliku või õigeusu kiriku pakutavast. Vähemalt Lääne-Eesti puhul võib käsitletud usuliikumisi pidada eestlastele ja eriti eestirootslastele isegi omasemaks või vähemalt rahvapärasemaks kui toonast luterlikku ja õigeusu kirikut, mida juhtisid valdavalt saksa või vene rahvusest vaimulikud. Kogu Eesti ulatuses võib teatud mööndustega sama väita ka 18. ja 19. sajandi vennasteliikumise kohta.

Mitmed uurijad on 18. ja 19. sajandi vennasteliikumist pidanud isegi eesti talurahva esimeseks rahvuslikuks (ärkamis)liikumiseks või siis selle eelkäijaks (vt nt Veem 1990: 66; Ilja 1995: 237). Seda eelkõige vennaste haridusliku ja kirjandusliku tegevuse, laulukooride ja muu ühistegevuse tõttu, mis aitas palju kaasa talurahva iseteadvuse kasvule. ${ }^{23}$ Kuigi tundub liialdus pidada vennasteliikumist rahvuslikuks ärkamiseks või isegi selle eelmänguks, ei tohiks selle usuliikumise sotsiaalkultuurilist mõju alahinnata. Rääkimata vennastekoguduse suurest osast talurahva sotsiaalses ja kultuurilises emantsipatsioo- 
nis, võib ka 19. sajandi lõpuveerandi ja 20. sajandi alguse Lääne-Eesti usuliikumistes näha omalaadseid ühiskondlikke liikumisi, mis sattusid vastuollu valitsevate ühiskonnakihtidega. Märkimist väärivad ka saavutused vaimuliku koorilaulu ja hariduse alal. Seda varjutas aga osa usuliikujate puhul kõige ilmaliku halvustamine. Käsitletud usuliikumiste kohatine rahvakultuurivaenulikkus ei anna aga põhjust alahinnata nende tähendust toonases eesti ja eestirootsi külaühiskonnas.

\section{Kommentaarid}

1 Artikkel on seotud projektiga ETF 7264.

2 Antud kontekstis ei käsitleta usuliikumistena Eesti ametlikus usuelus valitsenud luterlikku kirikut ja Vene Õigeusu Kirikut kui riigikirikut. Usuliikumiseks võiks küll lugeda eestlaste massilist siirdumist vene õigeusku 1840. aastatel, kuid siis oli tegu eeskätt sotsiaalsetest põhjustest ajendatud kirikuvahetusliikumisega, mitte aga inimese usu vahetusega. Enamik kirikut vahetanutest ei teadnud õigeusust suurt midagi ning paljud neist jätkasid luterliku kiriku külastamist ja luterlike kommete järgimist. Samuti on käsitlusest välja jäänud mõned väiksemad 18. ja 19. sajandi Eesti usuliikumised, mille laialdasemast mõjust rahvakultuurile andmeid ei ole (nt maltsvetlaste, reitslaste ja lästadiuslaste usuliikumised ning mitmed 19. sajandi lõpul tekkinud väiksemad vabakogudused (nende kohta vt Erviö 1936; Talonen 1988; Plaat 2001: 75-76, 140-141).

${ }^{3}$ Enamik selle talurahvakunsti loojatest artiklis käsitletaval perioodil oma sellelaadset tegevust/loomingut muidugi kunstiks ei nimetanud (vt ka Vunder 1998).

${ }^{4}$ Viimase väite tõestusi ja põhjusi vt Plaat 2001; Plaat 2003b.

${ }^{5}$ Eestirootslaste asustus oli Lääne- ja Loode-Eesti saartele ning rannikualadele tekkinud hiljemalt 13.-14. sajandist (Blees 1924: 5; Pöhl 1949: 170)

${ }^{6}$ Eestirootslaste usuliikumistest vt Plaat 2001.

${ }^{7}$ E. Gutsleff pandi koos Jämaja pastori Franz Hölterhofiga hernhuutluse pooldamise eest 1747. aastal Peterburi Peeter-Pauli kindlusesse vangi, kus E. Gutsleff 1749. aastal suri (vt Ilja 2000: 214-217, 229 jj).

8 Vt nt Sild 1934: 67; Põldmäe 1935: 127; Sild 1938: 185; Veem 1990: 48; ERA 5 1997: 1425; EA 1997: 142.

9 Terav vastuolu kiriklike ja ilmalike võimudega viis lõpuks Paabu vangistamiseni. Kuigi Paap lõpetas oma avaliku usumehena tegutsemise 1745. aastal, on veel 1750. aasta paiku Rõuge kihelkonnas leidunud lahkusulisi, kes keeldusid luterlikust armulauast ja kirikumaksudest ning matsid oma surnud väljapoole kiriku surnuaeda (Sild 1929: 102-106; Hiiemets 1940: 25; Plaat 1994: 1384-1385).

10 Toonase rahvausundi all peetakse silmas talurahva eelkristlike ja kristlike uskumuste sünkretistlikku segu, mida osa autoreid on nimetanud ka külakatoliikluseks. Vennastekoguduse liikmetele võisid ka katoliiklikud uskumused ja kombed tunduda ebausu ilmingutena. 
${ }^{11}$ Nii on teateid Vormsil 19. sajandi algul luterliku kiriku pastoraadi õuel tegutsenud palvemajast, mille kasutamist soovis piirata kohalik pastor Nikolaus Malmgren, kes proovis igati takistada saarel tugevasti levinud vennasteliikumist (Põldmäe 1979: 87). Keeluajal on vennaste tegevus lisaks Vormsile olnud aktiivsem veel Noarootsi, Osmussaare ja Hiiumaa Reigi rootslaste seas. Hiiurootslaste usuliikumine olevat aga vaibunud veel enne nende väljarändamist Ukrainasse 1781. aastal (Marrasch 1894: 21; Põldmäe 1940a: 89; Ilja 2000: 112, 119, 123, 200).

${ }^{12}$ Saare- ja Hiiumaa kogudustes tegutses 743 "töötajat” ehk talurahva hulgast esilekerkinud juhti ja aktiivsemat liiget. Saaremaal oli koguni 26 vennastekogudusse vastuvõetute kokkusaamiskohta-palvemaja ja 54 kohta avalike koosolekute pidamiseks. Ainult Pöide kihelkonnas polevat hernhuutlaste koosolekuid peetud. Hiiumaal oli 1801. aastal 6 vennaste palvemaja-kogunemispaika ja 23 lugemispaika. Mujal Eestis oli 1801. aastaks ehitatud 82 palvemaja (Philipp 1974: 388, 410411). Need arvud kinnitavad, et keeluaeg ei suutnud hernhuutlaste tegevust Eestis kaugeltki kaotada. Vennaste tegevuse elavnemisele on kaasa aidanud nende tegutsemiskeeldu leevendanud keisrinna Katariina II ukaas aastast 1764, mis andis usu- ja kirikuvabaduse välismaalastest vennastekoguduse liikmetele (vt Plaat 2001: 40).

${ }^{13}$ Hernhuutlaste võitlusest rahva joomapahega vt lähemalt Põldmäe 1938a.

14 Vaimus rändamine on levinud näiteks šamanistlikes usundites. See on andnud usundiloolasele Riho Saardile taevaskäijate puhul ainet mõtisklusteks Eesti "kristliku šamanismi” üle (suulised andmed).

${ }^{15}$ MNL 1822 (32-33): 255-261. Viljandi-, Viru- ja Tartumaa taevaskäijatest vt pikemalt Põldmäe 1935; VM 1933 (262-264); Plaat 1994: 1388-1391; Lääne- ja Hiiumaa taevaskäijatest vt Plaat 2001: 42-44.

16 Taevaskäijate kirjeldusi taevast ja põrgust koos sealsete asukatega vt Põldmäe 1935: 136-137, 149-150.

${ }^{17}$ Fantaasiarikkaid taeva- ja põrgunägemusi jäid aga edasi levitama 18.-19. sajandil vennastekoguduse liikmete seas liikunud nn taevakirjad (vt Prants 1937: 3; Põldmäe 1937).

${ }^{18}$ Tavaliselt vennastekoguduse rolli 18.-19. sajandi eestlaste kultuuriloos ja sotsiaalses emantsipatsioonis ülistavate (Arthur Võõbus, vt nt Võõbus 1968) või kiitvate eestlastest vennastekoguduste uurijate (nt Voldemar Ilja, Rudolf Põldmäe) kõrval on O. Looritsa suhtumine erandlik, kuid tema spetsialiteeti arvestades mõistetav.

19 Eesti prohvetite kohta 18.-20. sajandil vt lähemalt Plaat 1994.

${ }^{20}$ Vähesel määral olid aga Vormsil hakanud levima "linnariided" ja ka ehted. Vt Arepjevi venekeelne käsikiri "Vormsi saar ning selle rootslastest elanikud" VEM, f 1, n 2, s 17; Zassetskaja 1998: 107.

${ }^{21}$ Tavaliseks naisterõivaks oli punase-valgekirju rätik, mis kattis kahte patsi punutud juukseid, hele pluus või jakk, must villane plisseeritud seelik, oranžid sukad, mille peale tõmmati valged villased sokid, mustad pastlad ja käevarrel kantav tavaliselt punase-oranži tooniga riidest käekott (Pl 1928 (205); Pm 1930 (220): 4 \& 1932 (188): 4; vt Danell 1999: 84-85).

${ }^{22}$ Tollaste kirjelduste järgi olid veel 19. sajandi lõpul ja 20. sajandi algul Lääne- ja Hiiumaal tugevasti säilinud vanemad rahvauskumused ja kombed. Endiselt olevat olnud au sees targad või maa-arstid, kellelt saadi abi haiguste ja nõiduse korral. 
1880. aastate ajalehed väitsid, et arstide või haritumate inimeste asemel loodeti abi kaarditarkadelt, soolapuhujatelt ja nurgatohtritelt, kelle juures olevat endiselt palju käidud (EPm 1884 (26); Virulane 1884 (24). Kullamaal arstisid külaravitsejad peale omatehtud rohtude ka lausumistega. Näiteks rästikuhammustuse puhul kasutatud ussisõnu. Eriti naiste seas olevat leidunud palju neid, kes selliseid lausumisi, samuti kurja silma, ärategemist, luupainajat jms uskusid (Veiderma 1969: 76). Endiselt mängisid rahva elus suurt osa kodukäijad, tulihännad ja tondid. Igasuguseid õnnetusi püüdnud inimesed seletada kurja silma või muu nõidusega. Nii olevat usutud, et kuri inimene võib teisele elusolendile nõelussi, konna või siili sisse nõiduda (Martna 1914: 122-124). Isegi ühes peamises usuliikumiste keskuses Ridala kihelkonnas olnud veel 20. sajandi algul vana rahvausund või õigemini selle kristlusega segunenud sünkretistlik vorm laialt levinud. Nii nähtud sealkandis neljapäeviti tonte ja võideldud nendega. Unenägudesse usutud nii laialdaselt, et peaaegu igas peres olnud õpetlike raamatute asemel vaid unenägude seletaja. Haiguste ravimiseks kasutatud ussisõnu, rahaga hõõrumist, konna verd, musta kassi või muti karvadest põletatud tuhka ja tallaja vastu võideldud mõne vaimuliku raamatu lehtede abil (Olevik 1905: 871).

${ }^{23}$ Näiteks vaimuliku laulu edendajatena on hernhuutlased olnud teerajajateks mitte ainult eestlaste kogudustes, vaid ka Lääne- ja Hiiumaa eestirootslaste seas. 19. sajandi esimesel veerandil laienes ühehäälne laulmine Eesti vennastekogudustes juba mitmehäälsele koorilaulule, instrumentaalsaatele ja orkestrile (Põldmäe 1940c: 24jj). Vägagi oluline oli ka hernhuutlaste haridustegevus alates 18. sajandi keskpaigast. Lisaks lastele õppisid paljud täiskasvanud õed-vennad lugema ja kirjutama, tihti eelkõige selleks, et lugeda vennastekoguduse laialdast kirjavara. Eestlastest vendade endi kirjanduslik tegevus oli samuti märkimisväärselt aktiivne (vt lähemalt Põldmäe 1936, 1965; Võõbus 1968).

\section{Kasutatud allikad}

EAA - Eesti Ajalooarhiiv, Tartus

EKLA - Eesti Kultuurilooline Arhiiv, Eesti Kirjandusmuuseumis, Tartus

ERM - Eesti Rahva Muuseum, Tartus

ERM, EA - etnograafiline arhiiv

ERM, KV - korrespondentide vastuste arhiiv

ERM, TAp - topograafilise arhiivi päevikud

VEM - Venemaa Etnograafiamuuseum, Peterburis 
Kristlike usuliikumiste mõju eestlaste ja eestirootslaste rahvakunstile ja kultuurile

\section{Kirjandus}

Blees, Jakob 1924. Estlandssvenskarnas historia i korta drag. Stockholm: Norstedt.

Busch, Mihkel 1928. Ridala ärkamise ajalugu. Keila: Külvaja.

Danell, Gideon 1909. Baltiska svenskar I. Årsbok 1909. Göteborg, lk 13-34.

Danell, Sven 1999. Kuldrannake [mälestusi rannarootslastest]. Tartu: Ilmamaa.

Eckardt, Julius 1876. Livland im XVIII Jahrhundert I. Leipzig.

EA 1997 = Mäesalu, Ain \& Lukas, Tõnis \& Laur, Mati \& Tannberg, Tõnu. Eesti ajalugu I. Tallinn: Avita.

EBKAA 1911 = Eesti Baptisti koguduste ajaloolik album 25. juubeli aasta mälestuseks. Tallinn: J. Felsberg ja A. Tetermann.

Eisen, Matthias Johann 1921. Eesti prohvet Järve-Jaan. Tallinn: A. Keisermanni raamatukauplus.

EPm 1881 = Isamaalt. R. Läänemaalt. Rootsistamisest. Eesti Postimees 29, lk 114.

EPm 1884 = Harju maakonnast. Eesti Postimees, nr 26, 27. juuni.

ERA 5 = Libe, Juhan \& Oinas, August \& Sepp, Hendrik \& Vasar, Juhan (toim) 1997. Eesti rahva ajalugu 5. Tallinn: JK.

Erviö, Helle Kalervo 1936. Jooni lästadiusluse (laestadiusluse) levinemisest Eestis. Usuteadusline Ajakiri 3, lk 85-93.

Girgensohn, Reinhold 1869. Eberhard Gutsleff. Dorpater Zeitschrift für Theologie und Kirche IV. Dorpat. W. Gläser, lk 423-504.

Hiiemets, Johannes 1940. Õpetaja Quandti rasked päevad: peatükk kodumaa kirikuloost. Tartu: J. Hiiemets.

Ilja, Voldemar 1995. Vennastekoguduse (herrnhutluse) ajalugu Eestimaal (Põhja-Eesti) 1730-1743. Tallinn: Logos.

Ilja, Voldemar 2000. Vennastekoguduse (herrnhutluse) ajalugu Eestimaal (Pôhja-Eesti) 1744-1764. Tallinn: Logos.

Marrasch, Jacob 1894. Jakob Marrash'i elukäik, millest näha on missugune waim waimuliku elu poolest 150 aasta eest Saare- ja Hiiomaal walitses (ümberpannud C. F. J.). Revel: A. Mickwitz.

Jansen, Ea 1977. Eesti talurahva rahvusliku teadvuse kujunemisest XIX sajandil. Kahk, Juhan \& Jansen, Ea \& Vassar, Artur (toim). Eesti talurahva sotsiaalseid vaateid XIX sajandil. Tallinn: Eesti NSV Teaduste Akadeemia, lk 67-119. 
Jansen, Ea 1987. Ilmalik ja kiriklik Eesti talurahva maailmavaates XIX sajandil. Kivimäe, J (koost). Religiooni ja ateismi ajaloost Eestis 3. Artiklite kogumik. Tallinn: Eesti Raamat, lk 192-220.

Kaups, Richard 1974. Hea sõnum ja Eesti baptisti kogudused. Santa Barbara.

KPSL 1963 = Lätt, S \& Rüütel, Ingrid (koost). Kelle peale sa loodad. Valimik usu ja kiriku vastaseid rahvaluuletekste. Tallinn:

KPL 1930 = Vaimu tuul ehk ärkamine 1877. aastal Läänemaal, mis pärast üle Eestimaa laiali lagunes. Kristlik Perekonna leht 3-6.

Loorits, Oskar 1932. Vanavara kultuuriloo teenistusse! Vanavara vallast. Õpetatud Eesti Seltsi kirjad 1. Tartu: Õpetatud Eesti Selts, lk 35-58.

Läänemaa 1938 = Haberman, Harald (peatoim) \& Kant, Edgar \& Kruus, Hans \& Luha, Artur \& Tammekann, August Ferdinand \& (toim). Läänemaa 1.Üldosa: maateaduslik, majanduslik ja ajalooline kirjeldus. Tartu: Eesti Kirjanduse Selts.

Martna, Mihkel 1914. Külast: Mälestused ja tähelepanekud Eesti külaelu arenemisest pärast 60-id aastaid. Tallinn: Maa.

Meie Maa 1932 = J. A. Põllumees. Vormsi saar. Meie Maa 121, lk 3.

MNL 1822 = Taevaskäijatest ehk nõrkujaist. Marahwa Näddala-Leht 32 \& 33, lk $255-261$.

Masso, N. 1928. Eesti prohvet Jaagori Jaan. Eesti Kirjandus 10, lk 561-565.

Mägi, Toomas 1999. Karjane ja kari: luterlik kirik Saaremaal 18. sajandil. Magistritöö. Tartu: käsikiri Tartu Ülikooli raamatukogus.

Normann, Paul 1885. Die geistliche Bewegung im Kirchspiel Pühhalep. Mittheilungen und Nachrichten für die evangelische Geistlichkeit Russlands 41. Dorpat: C. C. Ulmann, lk 106-117.

Olevik 1896. Kõne Eesti vanavara korjamisest muinasaja uurijate kongressil Riias Augusti kuus 1896. Pidanud Peterburi Eesti õpetaja dr. J. Hurt. Olevik 50, 113.

Philipp, Guntram 1974. Die Wirksamkeit der Herrnhuter Brüdergemeinde unter den Esten und Letten zur Zeit der Bauernbefreiung (vom Ausgang des 18. bis über die Mitte des 19. Jhs.) Forschungen zur internationalen Sozial- und Wirtschaftsgeschichte 5. Köln \& Wien: Böhlau.

Plaat, Jaanus 1994. Eesti prohvetid ja prohvetlus 18.-20. sajandil. Looming 9, lk 1246-1254; 10, lk 1384-1402.

Plaat, Jaanus 1999. Vormsi usk: usuliikumised Vormsi rootslaste ja eestlaste seas 1740.-1990. aastail. Akadeemia 2, lk 277-309.

Plaat, Jaanus 2001. Usuliikumised, kirikud ja vabakogudused Lääne- ja Hiiumaal: usü̈henduste muutumisprotsessid 18. sajandi keskpaigast kuni 20. sajandi lõpuni. Eesti Rahva Muuseumi Sari 2. Tartu: Eesti Rahva Muuseum. 
Plaat, Jaanus 2003a. Religious Change in Estonia and the Baltic States during the Soviet Period in Comparative Perspective. Journal of Baltic Studies 1, Spring 2003, lk $52-73$.

Plaat, Jaanus 2003b. Saaremaa kirikud, usuliikumised ja prohvetid 18.-20. sajandil. Tartu: Eesti Rahva Muuseum.

Pl 1928 = Matsby. Üks kodune välismaareis. Vormsi saarele. Päevaleht 205, lk 2.

Pm 1930 = Vanade skandinaavlaste järeltulijate hulgas. Postimees 220, lk 4.

Pm 1932 = G. R-nk. Vormsi kuningriigis. Postimees 188, lk 4.

Prants, Hindrik 1937. Minu elukäik: mälestusi ja pärimusi. Tartu: Eesti Kirjanduse Selts.

Põldmäe, Rudolf 1935. Taevakäijad. Kaleviste mailt. Õpetatud Eesti Seltsi Kirjad 3. Tartu: Õpetatud Eesti Selts, lk 123-176.

Põldmäe, Rudolf 1936. Eesti vennastekoguduse kirjandusest XVIII sajandi keskel. Eesti Kirjandus 6, lk 249-269; 7, lk 324-343.

Põldmäe, Rudolf 1937. Se Velle Lütseppa Jani ello käuk siin ma pääl ehk Sääl taivan. Eesti Kirjandus 12, lk 611-618.

Põldmäe, Rudolf 1938a. Eesti vennastekoguduse võitlusest rahva joomapahega. Eesti Kirjandus 6, lk 281-293.

Põldmäe, Rudolf 1938b. Rahvaluulekorjaja tööradadelt. Eesti Kirjandus 10, lk 433445 .

Põldmäe, Rudolf 1940a. Dagösvenskarna och den herrnhutiska väckelsen på 1700talet. Svio-Estonica. Årsbok. Utgiven av Svensk-Estniska Samfundet vid Tartu Universitet 1939. Tartu, lk 78-89.

Põldmäe, Rudolf 1940b. Eesti ainestik Vennaste-uniteedi arhiivis Herrnhutis Saksamaal. Ajalooline Ajakiri 2, lk 73-84.

Põldmäe, Rudolf 1940c. Vennastekoguduse muusikalisest tegevusest meie maal. Tartu (käsikiri Eesti Teatri ja Muusikamuuseumi arhiivis: MO 143: 6).

Põldmäe, Rudolf 1958. Etnograafilisi ja olustikulisi andmeid vennastekoguduse allikais (käsikiri Eesti Rahva Muuseumi arhiivis: EA V II, lk 385-481).

Põldmäe, Rudolf 1959. Kirikutegelaste vastuolusid Jakob Hurda rahvaluulekogumisega. Keel ja Kirjandus 7, lk 409-421.

Põldmäe, Rudolf 1965. Hernhuutlik kirjasõna XVIII sajandil ja XIX sajandi algul. Vinkel, Aarne (toim). Eesti kirjanduse ajalugu viies köites 1. Esimestest algetest XIX sajandi 40-ndate aastateni. Tallinn: Eesti Raamat.

Põldmäe, Rudolf 1979. Lisaandmeid eesti talurahva elu kohta XVIII sajandil ja XIX sajandi alguses. (Hernhuutlike allikate põhjal). Põldmäe, Rudolf. Kultuuriloolisi vahelugemisi. Tallinn: Eesti Raamat, lk 67-101. 
Pöhl, Hj. 1949. Eesti-rootslaste usuline elu. Jumala abiga edasi: piiskop dr. Johan Kõpp’u 75. sünnipäevaks. Stockholm: EELK Konsistoorium Eksiilis, lk 170-176

Russwurm, Carl 1855. Eibofolke oder die Scweden an den Küsten Ehstlands und auf Runö II. Eine historisch-etnographische von der Kaiserlichen Akademie der Wissenschaffen zu St. Petersburg mit einem demidowscdhen Preise gekrönte undersuchung von K. Russwurm, Inspector der Schulen zu Hapsal mehrerer gelehrten Gesellschaften Mitgliede. Mit Urkunden, Tabellen und litographirten beilagen. Reval: In Comission bei Fr. Fleischer in Leipzig (http://books.google.ee/books?id=v6IBAAAAQAAJ\&dq= $\% 22$ Eibofolke+oder+die+Scweden+an+den+K\%C3\%BCsten+Ehstlands+und+auf+Run\% C3\%B6+\%22\&hl=en\&source=gbs_navlinks_s -29 . juuni 2009).

Schultz, Woldemar 1880. Die neue Bewegung unter dem ehstländischen Landvolk. Baltische Monatsschrift 7, lk 579-588.

Sild, Olaf 1928. August Hermann Francke mõjud meie maal = Die Einflüsse August Hermann Franckes auf das kirchliche und geistige Leben in Estland und Livland. Referat. Tartu: K. Mattiesen.

Sild, Olaf 1929. Tallima Paap. Usuteadusline Ajakiri 3/4. Tartu: K. Mattiesen, lk 97129 .

Sild, Olaf 1934. Kodumaa kiriku suhted vennaste kogudusega minevikus. Tartus usuteadlaste konverentsil peetud kõne. Eesti Kirik 9-15.

Sild, Olaf 1935. Üksikasju taevakäijate liikumisest mõningate säilinud kohtuaktide valgustusel. Usuteadusline Ajakiri 4. Tartu: K. Mattiesen, lk 109-120.

Sild, Olaf 1938. Eesti kirikulugu vanimast ajast olevikuni. Tartu: Akadeemiline Kooperatiiv.

Talonen, Jouko 1988. Viron lestadiolaisuus 1886-1953. Rovaniemi: Pohjois-Suomen Historiallinen Yhdistys.

Tuttar, Hindrek \& Dahl, Harald Victor 1929. Eesti baptismi ajalugu I. Ärkamise aeg. Tallinn: E.B.K. Selts.

Zassetskaja, Marina 1998. Germaani rahvaste kogud Venemaa Etnograafiamuuseumis. Eesti Rahva Muuseumi Aastaraamat XLII. Tartu, lk 97-115.

Valentin, Aron 1938. Svensk-Estlands apostel. Stockholm: Harrier.

Valgus 1884 = Omalt maalt. Meile kirjutatakse Läänemaa usuhullustajate üle järgmiselt. Valgus 5, lk 2 .

Veem, Konrad 1990. Eesti vaba rahvakirik: Dokumentatsioon ja leksikon. [2. täiendatud trükk.] Stockholm: Eesti Vaimulik Raamat.

Veiderma, A. 1969. Mõnda endistest aegadest. Mälestusi käidud eluteelt. Tallinn (Käsikiri Eesti Rahva Muuseumi arhiivis: KV 204) 
Virulane $1884=$ Wirulane, $\mathrm{nr} 24,1884$

VM $1933=$ R. P. Üks prohvetilugu Virumaalt. Usumäratseja mineva sajandi algul. Vaba Maa 262-264, lk 4.

Vunder, Elle 1998. Rahvakunst. Viires, Ants \& Vunder, Elle (koost \& toim). Eesti rahvakultuur. Tallinn: Eesti Entsüklopeediakirjastus, lk 513-543.

Võõbus, Arthur 1968. Contributions of the Herrnhuters to the Spiritual, Educational and Cultural Life in Estonia. Yearbook 1964-1967. The Estonian Learned Society in America. New York.

Wennerström, Thorsten 1931. Svenskarna i Finland och Estland: kortfattad redogörelse över deras svensknationella samlingsrörelse efter skilsmässan från Sverige. Göteborg: Riksföreningen för svenskhetens bevarande i utlandet.

Österblom, Lars Johan 1927. Svenskarna i Östersjöprovinserna. Samt En samling intressanta berättelser från Estland. 3. illustreeritud väljaanne. Karlshamn.

\section{Summary}

\section{The Impact of Christian Religious Movements on the Folk Art and Culture of Estonians and Estonian Swedes}

\section{Jaanus Plaat}

Key words: Estonian Swedes, folk art, folk culture, Moravian Brethren, religious movements

In the 18th-19th century, several Protestant religious movements spread in Estonia. These movements were partly active within the so far predominant Lutheran Church, though mostly outside it, and were sometimes followed by members of the Orthodox Church. The most influential of the movements were the Brethren movement and that of 'Heaven-goers', and also the religious movements of awakening which spread mostly in the final quarter of the 19th century in western Estonia and which led to the establishment of the first Free Congregations in Estonia (Baptists, Irvingites, Free Believers' congregations, Methodists). These religious movements have often contested several phenomena of folk culture of Estonians and Estonian Swedes, among these the phenomena of folk religion and folk art that some members of the movement have regarded as 'pagan' or sinful. As a result, fancier clothes, jewellery and musical instruments were destroyed in the heyday and the core areas of the movement (mostly in West Estonia); also, certain folk songs and dances of the agrarian community were abandoned and the narrative tradition underwent significant changes. The conflict with folk religion (with elements of prehistoric and Catholic beliefs) led to the destruction of prehistoric sacred sites and a dramatic change in the worldview of a part of the 
local peasantry. The 18th- to 19 th-century Brethren movement was particularly successful in these activities. A characteristic feature of the Brethren congregation, the 'Heaven-goers', and other religious movements in the late 19th century was certain asceticism and requirement of high morals. The impact of these religious movements on folk culture, however, was limited only to the faithful and did not affect the entire village community. A more dramatic change in the beliefs and lifestyle of the people took place on the West-Estonian islands of Saaremaa and Hiiumaa, in Lääne County in West Estonia and, most noticeably, in the parish inhabited by Estonian Swedes. Even so, the sometimes hostile attitudes of the mentioned religious movements towards folk culture give no reason to underrate their significance and positive influence for the Estonian and Estonian-Swedish agrarian population of the time. 